\title{
PENINGKATAN PRESTASI BELAJAR PENDIDIKAN AGAMA ISLAM MELALUI METODE JIGSAW LEARNING DI KELAS III SD NEGERI MUHARA KECAMATAN PACET KABUPATEN CIANJUR
}

\author{
Santana Taqwa \\ tarakanalada3905@gmail.com
}

\begin{abstract}
This research is an effort to improve learning achievement by applying jigsaw learning method to grade 3 students at Muhara Elementary School Subdistrics Pacet Districs Cianjur. By applying the jigsaw learning method is expected to improve the quality of learning so that the increase in learning achievement. The design of this research is action research with the subject of third grade students Muhara Elementary School Subdistrics Pacet Districs Cianjur. The data collection in this research is done by observation and written test each individual and group at the end of the lesson. Data obtained from each cycle were analyzed by qualitative and quantitative descriptive. The result of the study showed that the students 'involvement increased which had an impact on the students' learning achievement has improved after the implementation of learning by applying the jigsaw learning method, with the following result: in cycle I average grade 63,75 (36,4\% learning comprehension) 70 (51,5\%) in cycle II and more increase again in cycle III to 84 (87,9\%).
\end{abstract}

Keywords: Learning Achievement, Islamic Religious Education, Jigsaw Learning Method

\begin{abstract}
Abstrak : Penelitian ini merupakan upaya untuk peningkatan prestasi belajar dengan menerapkan metode jigsaw learning pada siswa kelas III A SD Negeri Muhara Kecamatan Pacet Kabupaten Cianjur. Dengan menerapkan metode jigsaw learning diharapkan dapat meningkatkan kualitas pembelajaran sehingga terjadi peningkatan prestasi belajar. Desain penelitian ini adalah penelitian tindakan dengan subjek siswa kelas III A SD Negeri Muhara Kecamatan Pacet Kabupaten Cianjur. Pengumpulan data dalam penelitian ini dilakukan dengan cara melakukan observasi dan tes tertulis setiap individu dan kelompok pada akhir pelajaran. Data yang diperoleh dari tiap- tiap siklus dianalisis dengan deskriptif kualitatif dan kuantitatif. Hasil penelitian menunjukan bahwa keterlibatan siswa meningkat yang berdampak pada prestasi belajar siswa mengalami peningkatan setelah dilaksanakan pembelajaran dengan menerapkan metode jigsaw learning, dengan hasil sebagai berikut: pada siklus I rata-rata nilai kelas 63,75 (ketuntasan belajar 36,4\%) meningkat menjadi 70 (51,5\%)pada siklus II dan lebih meningkat lagi pada siklus III menjadi 84 (87,9\%). Kata Kunci : Prestasi Belajar, Pendidikan Agama Islam, Metode Jigsaw Learning
\end{abstract}

\section{PENDAHULUAN}

Proses pembelajaran yang dilakukan oleh sebagian besar guru masih ada yang cenderung lebih mementingkan pada penghafalan konsep, bukan pada pemahaman. Hal ini dapat dilihat dari kegiatan pembelajaran di dalam kelas yang selalu didominasi oleh guru. Dalam penyampaian materi, biasanya guru menggunakan metode yang monoton seperti metode ceramah, di mana siswa hanya duduk, mencatat, dan mendengarkan apa yang disampaikan guru dan sedikit peluang bagi siswa untuk bertanya, sehingga siswa merasa jenuh dalam mengikuti proses pembelajaran. Dengan demikian, suasana pembelajaran menjadi tidak kondusif karena siswa menjadi pasif.

Kondisi seperti itu terjadi pula pada kegiatan pembelajaran mata pelajaran Pendidikan Agama Islam di kelas III SD Negeri Muhara Kecamatan Pacet Kabupaten Cianjur. Kondisi awal kegiatan belajar mengajar di kelas tersebut untuk mata pelajaran Pendidikan Agama Islam menunjukkan hasil belajar siswa rendah dan belum mencapai kriteria ketuntasan belajar (KKM), ini dapat dilihat dari 33 siswa, 17 orang siswa atau $50 \%$ siswa kelas III nilainya kurang dari 65 sebagai batas KKM. Hasil refleksi diri 
menunjukkan bahwa rendahnya prestasi belajar tersebut diantaranya sikap pasif siswa dalam proses pembelajaran, proses pembelajaran yang kurang bervariasi dan monoton, serta dominasi guru masih sangat besar sehingga siswa kurang mandiri yang berpengaruh terhadap prestasi belajar.

Guru seyogyanya mampu menentukan metode pembelajaran yang dipandang dapat membelajarkan siswa secara aktif melalui proses pembelajaran yang dilaksanakan agar tujuan pembelajaran dapat tercapai secara efektif dan hasil belajarpun dapat lebih ditingkatkan. Hal terpenting dalam kegiatan pembelajaran adalah terjadinya proses belajar (learning process) pada diri siswa.

Djamarah (1994, h. 19) menyatakan bahwa prestasi adalah hasil dari suatu kegiatan yang telah dikerjakan, diciptakan baik secara individu maupun secara kelompok. Sedangkan belajar menurut Slameto (2001, h. 2) adalah suatu proses usaha yang dilakukan seseorang untuk memperoleh suatu perubahan tingkah laku yang baru secara keseluruhan, sebagai hasil pengalamannya sendiri dalam interaksi dengan lingkungannya. Jadi prestasi belajar adalah hasil atau taraf kemampuan yang telah dicapai siswa setelah mengikuti proses belajar mengajar dalam waktu tertentu baik berupa perubahan tingkah laku, keterampilan dan pengetahuan dan kemudian akan diukur dan dinilai yang kemudian diwujudkan dalam angka atau pernyataan.

Banyak faktor yang bisa mempengaruhi terhadap keberhasilan pencapaian prestasi belajar seorang siswa. Syah (2003, h. 130) menyatakan bahwa faktor tersebut bisa berasal dari dalam diri siswa itu sendiri, yang terdiri atas aspek fisiologis dan aspek psikologis, atau juga berasal dari luar diri siswa seperti lingkungan sosial dan lingkungan nonsosial. Selain itu, faktor lain yang dapat mempengaruhi prestasi belajar adalah dari pendekatan belajar yang dilakukan oleh guru dalam pelaksanaan pembelajaran agar konsep yang disajikan bisa mudah diadaptasi oleh siswa.

Salah satu alternatif yang dapat dilakukan oleh guru untuk lebih mengaktifkan belajar siswa di kelas guna meningkatkan prestasi belajar adalah dengan menggunakan metode Jigsaw Learning. Ismail (2008, h. 82) menyatakan bahwa Jigsaw Learning adalah belajar melalui tukar delegasi antarkelompok. Sementara itu Zaini dkk (2004, h 58) berpendapat bahwa metode Jigsaw Learning adalah suatu tipe pembelajaran kooperatif yang terdiri dari beberapa anggota dalam satu kelompok yang bertanggung jawab atas penguasaan bagian materi belajar dan mampu mengajarkan bagian tersebut kepada anggota lain dalam kelompoknya.

Jigsaw Learning dapat diterapkan dalam kurikulum apa saja, bidang studi apa saja, dan kelas yang bagaimanapun keadaannya. Penerapan Jigsaw Learning dalam kelas cukup mudah. Secara garis besar langkah-langkahnya adalah sebagai berikut: (1) pemilihan materi pelajaran yang dapat dibagi menjadi beberapa segmen (bagian), (2) membagi siswa menjadi beberapa kelompok sesuai dengan jumlah segmen yang ada, jika jumlah siswa ada 25 sementara jumlah segmen yang ada adalah 5, maka masingmasing kelopmok terdiri dari 5 orang, (3) setiap kelompok mendapat tugas membaca, memahami dan mendiskusikan serta membuat ringksan materi pelajaran yang berbedabeda, (4) setiap kelompok mengirimkan anggotanya ke kelompok lain untuk 
menyampaikan apa yang telah mereka pelajari di kelompoknya, (5) mengembalikan suasana kelas seperti semula kemudian tanyakan sekiranya ada persoalan-persoalan yang tidak terpecahkan dalam kelompok, (6) menyampaikan beberapa pertanyaan kepada siswa untuk mengecek pemahaman mereka terhadap materi, (7) serta melakukan kesimpulan, klarifikasi dan tindak lanjut.

Berdasarkan permasalahan, fokus penyelidikan adalah peningkatan prestasi belajar PAI melalui metode jigsaw learning di kelas III SD Negeri Muhara. Penyelidikan ini bertujuan untuk mengungkap pengaruh metode jigsaw learning terhadap peningkatan prestasi belajar PAI di kelas III SD Negeri Muhara. Penelitian yang ditetapkan berupa penelitian tindakan kelas. Prosedur dan langkah-langkah penelitian mengikuti prinsipprinsip dasar yang berlaku dalam penelitian tindakan. Subjek yang dikenai tindakan adalah siswa kelas III A SD Negeri Muhara dengan jumlah 33 siswa.

\section{METODOLOGI PENELITIAN}

Metode yang digunakan dalam pelaksanaan penelitian ini adalah Penelitian Tindakan Kelas. Menurut Mulyasa (2009, h 11) menyatakan bahwa "Penelitian Tindakan Kertas adalah suatu upaya untuk mencermati kegiatan belajar sekolompok peserta didik dengan memberikan sebuah tindakan (treatment) yang sengaja dimunculkan, tindakan tersebut dilakukan oleh guru bersama-sama peserta didik atau oleh peserta didik dibawah bimbingan dan arahan guru, dengan maksud untuk memperbaiki dan meningkatkan hasil pembelajaran".

Tujuan Penelitian Tindakan Kelas menurut Arikunto (2008, h 18) adalah untuk memperbaiki berbagai persoalan nyata dan praktis dalam peningkatan mutu pembelajaran di kelas yang dialami langsung dalam interaksi antara guru dengan siswa yang sedang belajar. Penelitian ini dilakukan dalam 3 (tiga) siklus, yang pada setiap siklusnya terdiri dari empat tahapan. Empat tahapan tersebut sebagaimana menurut Mulyasa (2009, h 73) yaitu perencanaan, tindakan, observasi dan refleksi.

\section{HASIL KAJIAN DAN PEMBAHASAN}

Penelitian dilaksanakan di Kelas III A SD Negeri Muhara Kecamatan Pacet Kabupaten Cianjur dengan waktu penelitian terbagi ke dalam tiga siklus. Mata pelajaran yang menjadi objek penelitian tindakan kelas ini adalah Pendidikan Agama Islam (PAI), sesuai dengan silabus pada saat penelitian ini dilaksanakan, maka pokok bahasan yang diambil adalah kisah keteladanan nabi, dengan Kompetensi Dasar (KD): (a) memiliki sikap rasa ingin tahu, sabar dan rela berkorban sebagai implementasi dari pemahaman kisah keteladanan Nabi Ibrahim as. dan Nabi Ismail as, (b) mengetahui kisah keteladanan Nabi Ibrahim as. dan Nabi Ismail as. (rasa ingin tahu, sabar dan rela berkorban, hormat dan patuh kepada orangtua), dan (c) menceritakan kisah keteladanan Nabi Ibrahim as. dan Nabi Ismail as.

Jumlah siswa kelas III A SD Negeri Muhara yang dijadikan objek penelitian tindakan kelas ini berjumlah 33 siswa, terdiri dari 14 siswa laki-laki dan 19 siswa perempuan, dengan karakteristik siswa yang digambarkan sebagai berikut: 


\begin{tabular}{|c|c|c|c|c|}
\hline No & Nama Siswa & $\begin{array}{c}\text { Jenis } \\
\text { Kelamin }\end{array}$ & $\begin{array}{c}\text { Tempat, Tanggal } \\
\text { Lahir }\end{array}$ & $\begin{array}{l}\text { Pekerjaan } \\
\text { Orang Tua }\end{array}$ \\
\hline 1 & Andini Andiasa & $\mathrm{P}$ & Cianjur, 16-06-2007 & Buruh Tani \\
\hline 2 & Dedi Ahmad Junaedi & $\mathrm{L}$ & Cianjur, 25-06-2008 & Buruh Tani \\
\hline 3 & Deuis & $\mathrm{P}$ & Cianjur, 02-06-2008 & Buruh Tani \\
\hline 4 & Dewi Susanti & $\mathrm{P}$ & Cianjur, 02-04-2006 & Buruh Tani \\
\hline 5 & Fitri & $\mathrm{P}$ & Cianjur, 20-09-2009 & Buruh Tani \\
\hline 6 & Fitri Indriyani & $\mathrm{P}$ & Cianjur, 04-07-2007 & Buruh Tani \\
\hline 7 & Gilang & $\mathrm{L}$ & Cianjur, 14-05-2007 & Buruh Bangunan \\
\hline 8 & Jaeni & $\mathrm{L}$ & Cianjur, 11-02-2007 & Buruh Tani \\
\hline 9 & Jihan Siti Nurlaela & $\mathrm{P}$ & Cianjur, 22-08-2008 & Wiraswasta \\
\hline 10 & M. Albar Barokah & $\mathrm{L}$ & Cianjur, 02-08-2008 & Buruh Bangunan \\
\hline 11 & M. Despinugraha & $\mathrm{L}$ & Cianjur, 14-05-2008 & Wiraswasta \\
\hline 12 & M. Iqbal Badriansyah & $\mathrm{L}$ & Cianjur, 15-07-2007 & Wiraswasta \\
\hline 13 & M. Hasbuloh & $\mathrm{L}$ & Cianjur, 28-07-2009 & Wiraswasta \\
\hline 14 & M. Japar & $\mathrm{L}$ & Cianjur, 05-06-2007 & Buruh Bangunan \\
\hline 15 & M. Lutfi Tamimi & $\mathrm{L}$ & Cianjur, 29-07-7007 & Wiraswasta \\
\hline 16 & M. Ramdani & $\mathrm{L}$ & Cianjur, 23-09-2007 & Buruh Tani \\
\hline 17 & Mutia Salma & $\mathrm{P}$ & Cianjur, 27-09-2007 & Buruh Tani \\
\hline 18 & Nopi Nurhayati & $\mathrm{P}$ & Cianjur, 18-10-2007 & Buruh Tani \\
\hline 19 & Nenti & $\mathrm{P}$ & Cianjur, 09-07-2006 & Buruh Tani \\
\hline 20 & Nopaldi & $\mathrm{L}$ & Cianjur, 05-10-2008 & Buruh Tani \\
\hline 21 & Nuri Maulida & $\mathrm{P}$ & Cianjur, 24-08-2008 & Buruh Tani \\
\hline 22 & Nurnapsiah & $\mathrm{P}$ & Metro, 07-04-2008 & Buruh Tani \\
\hline 23 & Paiz Alwan & $\mathrm{L}$ & Cianjur, 08-03-2008 & Buruh Tani \\
\hline 24 & Rahmat Hidayat & $\mathrm{L}$ & Cianjur, 28-04-2007 & Buruh Tani \\
\hline 25 & Sendi & $\mathrm{L}$ & Cianjur, 04-06-2007 & Buruh Tani \\
\hline 26 & Siti Anisah & $\mathrm{P}$ & Cianjur, 20-04-2008 & Wiraswasta \\
\hline 27 & Siti Guspita & $\mathrm{P}$ & Cianjur, 15-08-2008 & Buruh Tani \\
\hline 28 & Siti Nabila & $\mathrm{P}$ & Cianjur, 13-07-2008 & Buruh Tani \\
\hline 29 & Siti Riyanti & $\mathrm{P}$ & Cianjur, 17-01-2007 & Buruh Tani \\
\hline 30 & Siti Salma A & $\mathrm{P}$ & Cianjur, 17-06-2007 & Buruh Tani \\
\hline 31 & Siti Salma B & $\mathrm{P}$ & Cianjur, 18-07-2006 & Buruh Tani \\
\hline 32 & Siti Saropah & $\mathrm{P}$ & Cianjur, 01-07-2007 & Buruh Tani \\
\hline 33 & Yeni & $\mathrm{P}$ & Cianjur, 27-08-2006 & Buruh Tani \\
\hline
\end{tabular}

Dari tabel di atas dapat diketahui: (a) usia Siswa rata-rata 10 tahun, (b) latar belakang keluarga/orang tua mayoritas sebagai buruh tani, (c) tingkat kemampuan siswa, berdasarkan pengamatan selama peneliti mengajar adalah 8 siswa pandai, 15 siswa berkemampuan sedang dan 10 siswa lambat belajar.

Ketika menyebut Pendidikan Agama Islam, maka tujuan utama pembelajaran yang ingin dicapai mencakup dua hal, sebagaimana Majid dan Andayani (2004, h. 130) menyatakan bahwa PAI mendidik siswa untuk berperilaku sesuai dengan nilai-nilai atau akhlak Islam, serta mendidik siswa untuk mempelajari materi ajaran Islam berupa pengetahuan tentang ajaran Islam. Pada materi pokok yang dibahas dalam penelitian 
tindakan kelas ini sangat sesuai dengan dua cakupan tersebut di mana dalam materi yang diajarkan memuat akhlak dan pengetahuan tentang Islam.

\section{DESKRIPSI PELAKSANAAN PENELITIAN}

\section{Deskripsi Pelaksanaan Siklus I}

Siklus pertama penelitian ini dilaksanakan pada minggu ketiga bulan April yaitu pada hari Rabu tanggal 19 April 2017 dengan materi pokok kisah ketedanan nabi dengan indikator menjelaskan kisah keteladanan Nabi Ibrahim as. Tahapan dan langkah-langkah yang dilakukan peneliti adalah diawali dengan tahap perencanaan mencakup kegiatan penyusunan instrumen/lembar soal dan buku Pendidikan Agama Islam untuk kelas III, LKS (lembar kerja siswa) untuk kelas III, serta penyiapan buku paket sebagai sumber pembelajaran Pendidikan Agama Islam. Selanjutnya adalah tahap pelaksanaan. Dalam pelaksanaan penelitian, peneliti bertindak sebagai pengajar. Adapun kegiatan pembelajaran mengacu pada rencana pembelajaran yang telah disiapkan. Secara garis besar pelaksanan pembelajaran terdiri dari beberapa tahapan. Di mulai dari kegiatan awal, peneliti (guru) mengkondisikan kelas, mengabsen siswa, dan dilanjutkan dengan appersepsi. Pada kegiatan apersepsi peneliti mengadakan tanya jawab tentang kisah Nabi Ibrahim. Ketika siswa sudah secara serempak dan antusias dalam menjawab pertanyaan-pertanyaan tersebut, peneliti berkesimpulan bahwa perhatian siswa sudah terfokus pada pelajaran, maka kegiatan bisa dilanjutkan kegiatan inti. Sebelum menginjak pada kegiatan inti, peneliti terlebih dahulu membagi kelas menjadi 6 kelompok sesuai dengan jumlah materi yang akan dipelajari. Masing-masing kelompok ada yang terdiri dari 6 siswa dan ada yang 7 siswa.

Pelaksanaan Penelitian Tindakan Kelas ini terintegrasi dalam kegiatan pembelajaran sehari-hari sesuai jadwal pelajaran. Dalam tahap pelaksanaan meliputi kegiatan pre test secara lisan tentang kisah Nabi Ibrahim. Adapun tes lisan tersebut dilaksanakan secara individual. Setelah itu, fokus kegiatan dilanjutkan pada kegiatan siswa secara berkelompok. Satu kelompok mendapat bagian materi pelajaran yang akan dipelajari siswa sesuai dengan tujuan yang akan dicapai. Setiap kelompok mendapat tugas membaca, memahami dan mendiskusikan serta membuat ringkasan materi pembelajaran yang bebeda. Selain itu juga, setiap kelompok mengirimkan anggotanya ke kelompok lain untuk menyampaikan apa yang telah mereka pelajari di kelompoknya. Setelah kegiatan kelompok selesai dilaksanakan, suasana kelas dikembalikan seperti semula kemudian peneliti melakukan konfirmasi kepada tiap kelompok seandainya ada persoalan-persoalan yang tidak terpecahkan dalam kelompok.

Memasuki kegiatan akhir pembelajaran, peneliti menyimpulkan hasil kegiatan pembelajaran, klarifikasi, dan tindak lanjut. Pada akhir proses belajar siswa diminta untuk menjelaskan kisah keteladanan Nabi Ibrahim as sebagai tes akhir pembelajaran (post test) dengan tujuan untuk mengetahui tingkat keberhasilan siswa dalam proses belajar mengajar yang dilakukan. Dalam post test ini digunakan cara yang sama dengan pre test. Berikut prestasi belajar siswa pada siklus I: 


\begin{tabular}{|c|c|c|c|}
\hline No & Nilai & KKM & Keterangan \\
\hline 1 & 63 & 65 & Tidak Tuntas \\
\hline 2 & 63 & 65 & Tidak Tuntas \\
\hline 3 & 64 & 65 & Tidak Tuntas \\
\hline 4 & 57 & 65 & Tidak Tuntas \\
\hline 5 & 63 & 65 & Tidak Tuntas \\
\hline 6 & 63 & 65 & Tidak Tuntas \\
\hline 7 & 64 & 65 & Tidak Tuntas \\
\hline 8 & 60 & 65 & Tidak Tuntas \\
\hline 9 & 75 & 65 & Tuntas \\
\hline 10 & 57 & 65 & Tidak Tuntas \\
\hline 11 & 72 & 65 & Tuntas \\
\hline 12 & 75 & 65 & Tuntas \\
\hline 13 & 64 & 65 & Tidak Tuntas \\
\hline 14 & 49 & 65 & Tidak Tuntas \\
\hline 15 & 82 & 65 & Tuntas \\
\hline 16 & 84 & 65 & Tuntas \\
\hline 17 & 70 & 65 & Tuntas \\
\hline 18 & 60 & 65 & Tidak Tuntas \\
\hline 19 & 59 & 65 & Tidak Tuntas \\
\hline 20 & 55 & 65 & Tidak Tuntas \\
\hline 21 & 90 & 65 & Tuntas \\
\hline 22 & 76 & 65 & Tuntas \\
\hline 23 & 51 & 65 & Tidak Tuntas \\
\hline 24 & 40 & 65 & Tidak Tuntas \\
\hline 25 & 54 & 65 & Tidak Tuntas \\
\hline 26 & 55 & 65 & Tidak Tuntas \\
\hline 27 & 70 & 65 & Tuntas \\
\hline 28 & 70 & 65 & Tuntas \\
\hline 29 & 74 & 65 & Tuntas \\
\hline 30 & 42 & 65 & Tidak Tuntas \\
\hline 31 & 90 & 65 & Tuntas \\
\hline 32 & 41 & 65 & Tidak Tuntas \\
\hline 33 & 53 & 65 & Tidak Tuntas \\
\hline Jumlah & 2104 & & \\
\hline $\begin{array}{c}\text { Rata- } \\
\text { rata }\end{array}$ & 63,75 & & \\
\hline
\end{tabular}

Pada pelaksanaan pembelajaran siklus I hasil evaluasi menunjukkan dari 33 siswa ada 12 siswa yang memperoleh nilai 65 ke atas. Rata-rata kelas 63,75, ketuntasan belajar 36,4\%. Dari data tersebut dapat dilihat bahwa 33 siswa masih ada 19 siswa yang belum tuntas belajar. Hal ini disebabkan oleh beberapa kemungkinan yang diantaranya adalah peneliti dalam menggunakan metode masih secara monoton sehingga siswa merasa jenuh. Selain itu, proses pembelajaran didominasi oleh guru sehingga siswa kurang aktif dalam proses pembelajaran. 
Peneliti selanjutnya mengadakan refleksi atas hasil kegiatan pembelajaran pada siklus I. Refleksi dilakukan oleh peneliti berdasarkan dari dua hasil penelitian, yaitu hasil pengamatan situasi kelas/pembelajaran dan hasil perbandingan/peningkatan nilai post test dibanding nilai pre test. Pelaksanaan kegiatan pembelajaran pada siklus 1 ini masih terdapat kekurangan, karena dari 33 jumlah siswa, yang mendapat nilai di atas KKM hanya 12 siswa sehingga perlu adanya revisi untuk dilakukan pada siklus berikutnya. Perbandingan nilai ketuntasan post test terhadap pre test menjadi dasar perbaikan pada siklus berikutnya. Untuk mengatasi kelemahan-kelemahan tersebut peneliti harus memperbaiki pada kinerja siklus II. Bentuk perbaikan ditempuh dengan menerapkan metode jigsaw learning.

\section{Deskripsi Pelaksanaan Siklus II}

Siklus kedua penelitian ini dilaksanakan pada minggu keempat bulan April yaitu pada hari Rabu tanggal 26 April 2017 dengan materi pokok kisah ketedanan nabi dengan indikator menjelaskan hikmah kisah keteladanan Nabi Ibrahim. Tahapan dan langkahlangkah yang peneliti lakukan dalam siklus II ini tentu saja diwali dengan perencanaan terlebih dahulu. Perencanaan dalam siklus kedua ini dimulai dengan refleksi awal, yaitu peneliti melakukan perenungan berdasarkan evaluasi siklus pertama terhadap materi pembelajaran yang telah dilakukan menunjukkan kelemahan dalam hal respon siswa yang disebabkan karena siswa masih belum terlibat aktif, waktu yang digunakan belum efektif, ketrampilan guru masih kurang. Selanjutnya peneliti merancang kegiatan yang akana dilaksanakan pada siklus kedua dengan membuat RPP yang akan mengujicobakan penerapan metode jigsaw learning. Di samping itu, peneliti juga mempersiapkan instrumen penilaian dan lembar observasi.

Dalam pelaksanaan tindakan, peneliti didampingi oleh guru mitra melaksanakan pembelajaran sesuai dengan RPP yang telah disiapkan. Kegiatan pembelajaran kisah Nabi Ibrahim as dengan menerapkan metode jigsaw learning pada siklus II ini seperti pada pertemuan sebelumnya peneliti mengawali dengan melakukan presensi kehadiran siswa, dan kemudian dilanjutkan dengan melaksanakan pre test secara lisan tentang kisah Nabi Ibrahim as. Adapun tes lisan dilaksanakan kembali secara individual. Setelah selesai melaksanakan pre test, peneliti membagi kelas menjadi 5 kelompok. Jumlah kelompok menyesuaikan dengan jumlah bagian materi pelajaran yang akan dipelajari siswa yang akan dicapai sesuai dengan tujuan pembelajarannya Setiap kelompok mendapat tugas membaca, memahami dan mendiskusikan serta membuat ringkasan materi pembelajaran yang berbeda. Setiap kelompok juga mengirimkan anggotanya ke kelompok lain untuk menyampaikan apa yang telah mereka pelajari di kelompoknya. Setelah kegiatan kelompok selesai dilaksanakan, suasana kelas dikembalikan seperti semula kemudian peneliti melakukan konfirmasi kepada tiap kelompok seandainya ada persoalan-persoalan yang tidak terpecahkan dalam kelompok.

Memasuki kegiatan akhir pembelajaran, peneliti menyimpulkan hasil kegiatan pembelajaran, klarifikasi, dan tindak lanjut. Pada akhir proses belajar melaksanakan post test untuk mengetahui penguasaan materi pada siswa. Berikut prestasi belajar siswa (post test) pada siklus II: 


\begin{tabular}{|c|c|c|c|}
\hline No & Nilai & KKM & Keterangan \\
\hline 1 & 93 & 65 & Tuntas \\
\hline 2 & 61 & 65 & Tidak Tuntas \\
\hline 3 & 60 & 65 & Tidak Tuntas \\
\hline 4 & 50 & 65 & Tidak Tuntas \\
\hline 5 & 55 & 65 & Tidak Tuntas \\
\hline 6 & 62 & 65 & Tidak Tuntas \\
\hline 7 & 70 & 65 & Tuntas \\
\hline 8 & 70 & 65 & Tuntas \\
\hline 9 & 81 & 65 & Tuntas \\
\hline 10 & 75 & 65 & Tuntas \\
\hline 11 & 64 & 65 & Tidak Tuntas \\
\hline 12 & 77 & 65 & Tuntas \\
\hline 13 & 64 & 65 & Tidak Tuntas \\
\hline 14 & 50 & 65 & Tidak Tuntas \\
\hline 15 & 90 & 65 & Tuntas \\
\hline 16 & 85 & 65 & Tuntas \\
\hline 17 & 75 & 65 & Tuntas \\
\hline 18 & 63 & 65 & Tidak Tuntas \\
\hline 19 & 76 & 65 & Tuntas \\
\hline 20 & 79 & 65 & Tuntas \\
\hline 21 & 74 & 65 & Tuntas \\
\hline 22 & 92 & 65 & Tuntas \\
\hline 23 & 62 & 65 & Tidak Tuntas \\
\hline 24 & 60 & 65 & Tidak Tuntas \\
\hline 25 & 60 & 65 & Tidak Tuntas \\
\hline 26 & 74 & 65 & Tuntas \\
\hline 27 & 62 & 65 & Tidak Tuntas \\
\hline 28 & 83 & 65 & Tuntas \\
\hline 29 & 85 & 65 & Tuntas \\
\hline 30 & 57 & 65 & Tidak Tuntas \\
\hline 31 & 61 & 65 & Tidak Tuntas \\
\hline 32 & 60 & 65 & Tidak Tuntas \\
\hline 33 & 80 & 65 & Tuntas \\
\hline Jumlah & 2310 & & \\
\hline $\begin{array}{c}\text { Rata- } \\
\text { rata }\end{array}$ & 70 & & \\
\hline
\end{tabular}

Setelah dilaksanakan perbaikan pada siklus II hasil evaluasi menunjukkan peningkatan. Dari 33 siswa ada 17 siswa yang memperoleh nilai 65 ke atas. Rata-rata kelas yang semula 63,75 menjadi 70. Sedangkan ketuntasan belajar semula $36,4 \%$ menjadi $51,5 \% \%$, atau mengalami kenaikan $15,1 \%$. Perubahan strategi yang dilakukan mampu meningkatkan prestasi belajar siswa. Masih ada 16 siswa yang belum tuntas belajarnya. Peneliti memberikan bimbingan khusus kepada 16 siswa tersebut.

Berdasarkan hasil pengamatan selama berlangsung pembelajaran terhadap situasi kelas dan prestasi siswa, pelaksanaan kegiatan pembelajaran pada siklus II ini masih 
terdapat kekurangan, peneliti dapat menemukan kelemahan pembelajaran, di antaranya adalah siswa yang berkemampuan rendah masih kurang aktif dalam meringkas materi pelajaran dan dalam kelompok terlihat banyak diam selama kegiatan berlangsung. Selain itu, ada kelompok yang tidak berani menjelaskan ke kelompok lain karena malu. Peneliti melakukan refleksi bahwa dalam pelaksanaan siklus II masih terdapat kekurangan sehingga akan dilakukan perbaikan pada siklus III.

\section{Deskripsi Pelaksanaan Siklus III}

Siklus ketiga penelitian ini dilaksanakan pada minggu ke satu bulan Mei yaitu pada hari Rabu tanggal 3 Mei 2017 dengan materi pokok kisah keteladanan Nabi Ismail as dan hikmah dari kisah Nabi Ismail as. Dalam siklus ketiga peneliti melakukan perbaikan pembelajaran dengan pembentukan kelompok dengan mengadakan perubahan anggota kelompok yang aktif ke kelompok yang pasif. Tahapan dan langkahlangkah yang peneliti lakukan dalam siklus III diawali dengan refleksi awal, yaitu peneliti melakukan perenungan berdasarkan evaluasi siklus II pembelajaran Pendidikan Agama Islam (PAI), yang menunjukkan kelemahan pemahaman siswa terhadap penguasaan materi yang diajarkan. Kemudian fokus kepada permasalahan, pengelompokan siswa dari kelompok yang aktif ke kelompok pasif. Kelompok dibagi sama seperti siklus kedua hanya kelompok yang berkemampuan rendah/kelompok pasif dicampur dengan kelompok yang berkemampuan tinggi/kelompok aktif. Selain itu juga peneliti melakukan penyusunan Rencana Program Pembelajaran (RPP) dengan menerapkan metode jigsaw learning dengan Kompetensi Dasar (KD) mengetahui kisah keteladanan Nabi Ismail as.

Pada tahap pelaksanaan setelah peneliti mengkondisikan kelas, peneliti membagi kelas menjadi 5 kelompok sesuai dengan jumlah bagian materi pelajaran. Anggota kelompok diubah menjadi berbeda dengan kelompok sebelumnya. Setiap kelompok mendapat tugas membaca, memahami dan mendiskusikan serta membuat ringkasan materi pembelajaran yang berbeda. Setiap kelompok selanjutnya mengirimkan anggotanya (delegasi) ke kelompok lain untuk menyampaikan apa yang telah mereka pelajari di kelompoknya. Setelah kegiatan kelompok selesai dilaksanakan, suasana kelas dikembalikan seperti semula kemudian peneliti melakukan konfirmasi kepada tiap kelompok seandainya ada persoalan-persoalan yang tidak terpecahkan dalam kelompok.

Pada kegiatan akhir, peneliti memberikan pertanyaan kepada siswa untuk mengecek pemahaman mereka terhadap materi yang dipelajari. Kemudian peneliti melakukan tes untuk mengukur pencapaian prestasi belajar pada siklus III ini.

\begin{tabular}{|c|c|c|c|}
\hline No & Nilai & KKM & Keterangan \\
\hline 1 & 100 & 65 & Tuntas \\
\hline 2 & 70 & 65 & Tuntas \\
\hline 3 & 81 & 65 & Tuntas \\
\hline 4 & 72 & 65 & Tuntas \\
\hline 5 & 100 & 65 & Tuntas \\
\hline 6 & 80 & 65 & Tuntas \\
\hline 7 & 82 & 65 & Tuntas \\
\hline
\end{tabular}




\begin{tabular}{|c|c|c|c|}
\hline 8 & 91 & 65 & Tuntas \\
\hline 9 & 73 & 65 & Tuntas \\
\hline 10 & 90 & 65 & Tuntas \\
\hline 11 & 81 & 65 & Tuntas \\
\hline 12 & 100 & 65 & Tuntas \\
\hline 13 & 81 & 65 & Tuntas \\
\hline 14 & 92 & 65 & Tuntas \\
\hline 15 & 100 & 65 & Tuntas \\
\hline 16 & 93 & 65 & Tuntas \\
\hline 17 & 93 & 65 & Tuntas \\
\hline 18 & 82 & 65 & Tuntas \\
\hline 19 & 63 & 65 & Tidak Tuntas \\
\hline 20 & 90 & 65 & Tuntas \\
\hline 21 & 90 & 65 & Tuntas \\
\hline 22 & 83 & 65 & Tuntas \\
\hline 23 & 83 & 65 & Tuntas \\
\hline 24 & 64 & 65 & Tidak Tuntas \\
\hline 25 & 83 & 65 & Tuntas \\
\hline 26 & 83 & 65 & Tuntas \\
\hline 27 & 83 & 65 & Tuntas \\
\hline 28 & 100 & 65 & Tuntas \\
\hline 29 & 92 & 65 & Tuntas \\
\hline 30 & 50 & 65 & Tidak Tuntas \\
\hline 31 & 100 & 65 & Tuntas \\
\hline 32 & 90 & 65 & Tuntas \\
\hline 33 & 57 & 65 & Tidak Tuntas \\
\hline Jumlah & 2772 & & \\
\hline Rata- & 84 & & \\
rata & & & \\
\hline & & & \\
\hline
\end{tabular}

Setelah dilaksanakan pembelajaran siklus III, hasil evaluasi menunjukkan peningkatan dari pembelajaran siklus II. Peningkatan tersebut seperti berikut ini: Dari 33 siswa, ada 29 siswa yang berhasil mencapai ketuntasan belajar, rata-rata kelas adalah 84. Hasil evaluasi pada siklus III menunjukkan peningkatan, ketuntasan belajar mencapai $87,9 \%$ sedangkan semula 51,5\%, atau mengalami kenaikan $36,4 \%$. Perubahan strategi yang dilakukan mampu meningkatkan prestasi belajar siswa. Akan tetapi masih ada 4 siswa yang belum tuntas belajarnya. Peneliti memberikan bimbingan khusus kepada 4 siswa tersebut sebagai tindak lanjut hasil evaluasi siklus III.

Berdasarkan hasil pengamatan selama berlangsung pembelajaran terhadap situasi kelas dan prestasi siswa pelaksanaan kegiatan pembelajaran pada siklus III, peneliti menemukan berbagai keunggulan dengan menerapkan metode jigsaw learning antara lain: (1) siswa semakin aktif dalam pembelajaran, (2) meningkatkan rasa tanggungjawab siswa terhadap pembelajarannya sendiri dan juga pembelajaran orang lain, (3) siswa tidak hanya mempelajari materi yang diberikan, tetapi mereka juga harus siap memberikan dan mengajarkan materi tersebut pada anggota kelompok yang lain, (4) 
siswa saling tergantung satu dengan yang lain dan bekerja sama secara kooperatif untuk mempelajari materi yang ditugaskan, (5) melatih siswa agar terbiasa berdiskusi dan bertanggungjawab secara individu untuk membantu memahamkan tentang suatu materi pokok kepada teman sekelasnya.

Pada siklus III peneliti telah menerapkan metode pembelajaran Jigsaw learning dengan baik dilihat dari aktivitas siswa, perhatian serta keaktifan terhadap pembelajaran sudah mengalami peningkatan. Maka tidak perlu dilakukan revisi secara besar-besaran lagi, tetapi yang perlu diperhatikan untuk tindakan selanjutnya adalah memaksimalkan dan mempertahankan apa yang telah ada dengan tujuan agar pelaksanaan proses pembelajaran selanjutnya dengan metode jigsaw learning dapat meningkatkan proses pembelajaran sehingga tujuan pembelajaran dapat tercapai.

\section{SIMPULAN}

Dari hasil kegiatan pembelajaran dengan menerapkan metode jigsaw learning yang telah dilakukan selama tiga siklus, dapat disimpulkan bahwa pembelajaran dengan menerapkan metode jigsaw learnng memiliki dampak positif dalam meningkatkan prestasi belajar siswa. Hal tersebut dibuktikan dengan adanya peningkatan nilai rata-rata 63,75 pada siklus I, menjadi 70 pada siklus II dan meningkat lagi menjadi 84 pada siklus III. Keberhasilan proses pembelajaran ditandai dengan peningkatan ketuntasan belajar siswa dalam setiap siklus, yaitu siklus I (36,4\%), siklus II (51,5\%) siklus III (87,9\%).

Agar proses pembelajaran Pendidikan Agama Islam (PAI) lebih efektif dan lebih memberikan hasil yang optimal bagi siswa, maka peneliti memiliki rekomendasi sebagai berikut: (1) Guru Pendidikan Agama Islam (PAI) untuk dapat secara kreatif mencobakan dan mengembangkan model pembelajaran tersendiri yang khas, sesuai dengan kondisi nyata di tempat kerja masing-masing, sehingga pada gilirannya akan muncul model-model pembelajaran versi guru yang bersangkutan, yang tentunya semakin memperkaya khazanah model pembelajaran yang telah ada, (2) Guru harus dapat menjaga dan membina keterlibatan aktif siswa dalam kegiatan pembelajaran agar daya serap anak terhadap materi yang diberikan guru menjadi lebih mantap. (3) Kepada Kepala Sekolah diupayakan senantiasa memotivasi guru-guru di sekolahnya agar mengembangkan profesionalitasnya sebagai pendidik.

\section{DAFTAR PUSTAKA}

Abdul Majid dan Dian Andayani. (2004). PAI Berbasis Kompetensi (Konsep Dan

Implementasi Kurikulum 2004). Bandung: Remaja Rosdakarya.

E. Mulyasa. (2009). Praktik Penelitian Tindakan Kelas. Bandung: Rosdakarya.

Hisyam Zaini dkk. (2004). Strategi Pembelajaran Aktif. Yogyakarta: CTSD.

Ismail. (2008). Strategi Pembelajaran Agama Islam Berbasis PAIKEM. Semarang:

Rasail Media Group.

Muhibbin Syah. (2003). Psikologi Belajar, Jakarta: PT Raja Grafindo Persada.

Slameto. (2001). Belajar dan Faktor-Faktor yang mempengaruhinya. Jakarta: Bumi

Aksara. 
Santana Taqwa

Suharsimi Arikunto. (2008). Penelitian Tindakan Kelas. Jakarta: Bumi Aksara.

Syaiful Bahri Djamarah. (1994). Guru dan Anak Didik dalam Interaksi Edukatif.

Bandung: Rineka Cipta. 